\title{
FILOZOFICZNA KONCEPCJA PRAWA NATURALNEGO
}

W tym, co zostanie przedstawione, będzie mowa nie tyle o historycznie zaprezentowanych ujęciach prawa naturalnego, ile o samym prawie naturalnym. Interesować nas tu będą przede wszystkim pewne fakty $\mathrm{i}$ ich racje, a przedstawione dotąd teorie jedynie w związku z merytorycznie trafnym uchwyceniem i metodologicznie poprawnym wyjaśnieniem tychże faktów. Uwaga ta nie wydaje się zbędna na tle tego, co można zaobserwować $w$ niektórych współczesnych publikacjach na temat prawa naturalnego. Czytając je, można niekiedy odnieść wrażenie, jakby autorów interesowały mniej pewne zagadkowe fakty, aniżeli to, co kto myślał posługując się nazwą prawa naturalnego. Poszczególni autorzy porównują teorie prawa naturalnego ze sobą, zamiast porównać je z tym, z czym jedynie trzeba i od czego wyłącznie zależy to, czy tymi teoriami warto się w ogóle interesować ${ }^{1}$. Chodzi oczywiście o porównanie z faktami. Rozmyślnie zatem położymy akcent na empiryczne uprawomocnienie pojęcia prawa naturalnego, mniej zaś na dyskuję z opiniami o nim. Proponuje się więc ujęcie problemowe i syste-

1 Por. F. Wieacker, Zum heutigen Stand der Naturrechtsdiskussion, Köln 1965; F. Böckle, Das Naturrecht im Disput, Düsseldorf 1966; A. Arntz, La loi naturelle et son histoire, „Concilium”, 5 (1965) 41-57; Ph. Delhaye, Permanence du droit naturel, Louvain 1967; W. A. Luijpen, Phenomenology of Natural Law, Pittsburgh 1967. $\mathrm{Na}$ niektórych współczesnych ujęciach prawa naturalnego zdaje się także ciążyć to, co Brytyjczycy nazywają liking thinking. Usiłuje się mianowicie określić prawo natıralne w sposób pozwalający „podbudować” z góry postulowane szczegółowe rozstrzyg:nięcia. Por. np. J. H. Walgrawe, Morale et évolution, „Concilium”, 5 (1965) 27-39; E. Schillebeeckx, De naturrwet in verband met de katholike huvelijksopvatting, w: Jaarboek der Katholieke Theologen (1961), Hilversum 1963, 5-51. Artykuł ten jest omawiany obszernie przez F. Böckle, za którym go tutaj cytujemy: Bulletin zur innerkirchlichen Diskussion um die Geburtenregelung, „Concilium” 5 (1965) $411-426$. 
matyczne raczej, aniżeli erudycyjno-informacyjne. Autor uważa zresztą, że pogłębiona refleksja nad odnośnymi faktami prowadzi wprost do wyróżnienia pewnej, bynajmniej nie nowej, spośród zastanych teorii prawa naturalnego. Zadanie swe widzi głównie w sposobie przedstawienia jej zarysu ${ }^{2}$. Czytelnik sam osądzi, ile z tradycji, a ile nowego zawiera się w przedłożonej propozycji.

\section{§ 1. BAZA WYJSCIOWA: FAKT MORALNY}

Jakakolwiek teoria liczy się dla nas o tyle, o ile sama ona liczy się z faktami, a więc o ile fakty te trafnie rejestruje (zamiast ignorować) i wyjaśnia (zamiast poprawiać czy modyfikować). To fakty są czynnikiem kontrolnym dla teorii, nie teoria dla faktów. Ta oczywistość aż nazbyt często bywa ignorowana, może dlatego, że rzeczy oślepiająco jasnych łatwo nie dostrzec. Oczywiście, dostrzegając pewne fakty i usiłując je wyjaśnić nie podobna nie doceniać wysiłku innych i rezultatów ich badań. Byłoby zarozumiałością lekceważyć te badania. Własne widzenie i wyjaśnienie, należy zawsze kontrolować konfrontując je także $z$ widzeniem i wyjaśnieniem cudzym. Wszelako naczelnym źródłem i instancją kontrolną i dla własnego i cudzego widzenia musi być ostatecznie sama badana rzeczywistość, sam badany fakt. Ta instancja posiada ostateczny, definitywnie wiążący głos.

Rozważmy tedy pewien rodzaj faktów! Ja, drudzy, wszyscy, raz po raz stajemy $\mathrm{w}$ obliczu realnie danych sytuacji, dla których wyrażenia używamy zwrotów w rodzaju: „Powinienem to oto wobec ciebie, jego, jej, was, ich, każdego na twym miejscu, wszystkich”, czy też: „Powienieneś - i każdy inny na twym miejscu — to oto wobec mnie - i każdego innego na mym miejscu".

Nie sądzę, by komukolwiek $\mathrm{z}$ nas te konstatacje wydały się obce. Nic się więc nie podsuwa, ani wmawia, tylko stwierdza lub przypomina znane stwierdzenia. Tych ,powienienem” jest całe mnóstwo. Żyjemy pośród nich, więcej — żyjemy nimi, one wykreślają nasze ludzkie dzieje, ,jedyną naszą prawdziwą - jakby powiedział J. Steinbeck historię". Stanowią one wprost nieprzeliczalny rezerwuar faktów. Czy są to fakty jednorodne? Nie! Przynajmniej nie całkiem. A czy są jakieś możliwości ich klasyfikowania, czy przynajmniej selekcjonowania, porządkowania? Są. Można je w tym celu poddać prostym zabiegom selekcjonującym, wedle prostego kryterium: wedle tego, jak się w danym przypadku poszczególne ,powinienem” uzasadnia, motywuje. Nazwijmy te zabiegi "redukcjami”.

Gdy np. poddam te ,powinienem” redukcji jurydycznej i wyłowię

2 Będzie to jakby szkic wykładu etyki jako teorii prawa naturalnego. 
z ich grupy (czy też wyciągnę ,przed nawias”) te „powinienem”, które nimi są $z$ racji istnienia odpowiedniego aktu pozytywnego prawodawstwa (,,powinienem, ponieważ władza nakazuje”), wówczas pozostanie w grupie wyjściowej dużo jeszcze innych „powinienem” 3. Będą tam np. te, którymi się władza albo wcale nie interesuje, albo nawet takie, które w pewnych razach każą się jej przeciwstawić. Przypomina się tu proces Sokratesa 4, oraz „powinienem” związane z wydarzeniami, które swe apogeum znalazły $\mathrm{w}$ słynnym procesie norymberskim.

Fakty te można poddać $\mathrm{z}$ kolei redukcji etologicznej. Wyodrębnimy wówczas z interesującego nas zbioru wszystkie te „powinienem”, których racją i motywem jest: „ponieważ to się ceni, uznaje, potępia” 5 .

Można dalej dokonać redukcji prakseologicznej lub - poczynając od drugiego końca - teleologicznej: „powinienem, to oto, ponieważ w wyniku tego uzyskam upragnione tamto, ponieważ to mi zapewni tamto, ponieważ dzięki temu osiągnę: szczęście, doskonałość, pełny rozwój, samourzeczywistnienie, harmonię we współżyciu" ${ }^{6}$. W wyniku tej redukcji wyłowimy znowu mnóstwo ,powinienem” z naszego zbioru. Wszakże

3 Sądy powinnościowe mające swe oparcie w odpowiednich aktach stanowienia władzy społecznej nazywa się niekiedy normami tetycznymi. (M. Ossowska, Cz. Znamierowski). Istniały próby zinterpretowania norm moralnych jako norm tetycznych (niektórzy z sofistów, woluntaryści średniowieczni, niektórzy wspólcześni pozytywiści jak np. H. Kelsen, T. Geiger).

4 Plato, Obrona Sokratesa. Kriton, Warszawa 1958.

5 Podmiotem, który wyraża uznanie bądź potępienie nie jest tu jednak jak w przypadku norm tetycznych określona władza społeczna, leoz raczej mniej lub bardziej anonimowa opinia społecznego środowiska. Istniały także próby interpretowania powinności moralnej $w$ duchu tego typu etologizmu. Należy tu zaliczyć socjologizm etyczny Levy-Bruhla i E. Durkheima. Współcześnie bliski tej interpretacji jest emotywizm etyczny (Ch. Stevenson).

6 Próba redukowania norm (powinności) moralnych do norm prakseologicznych (teleologicznych) charakteryzuje stanowisko naturalizmu etycznego. Istnieją empirystyczne (np. M. Schlick) i nie-empirystyczne, metafizyczne jego odmiany (J. Maritain umiejscawia tu nawet Arystotelesa). U podstaw naturalizmu tkwi zazwyczaj niedostrzeganie specyfiki dziedziny moralności i utożsamianie jej z dziedzinami „przyległymi” (np. z dziedziną szczęściodążności). Najczęściej ingeruje tu podobnie zresztą jak w przypadku emotywizmu - pozytywistyczna doktryna epistemologiczna, zawężająca pole doświadczenia do samych tylko spostrzeżeniowo danych przedmiotów. Zawężenie to nie jest zgodne $\mathrm{z}$ samym doświadczeniem. Należy odróżnić naturalizm w uprawianiu etyki od naturalizmu metaetycznego. Chodzi o stopień języka, w jakim dokonuje się odnośnej refleksji. Przykładem pierwszego będzie eudajmonizm w najrozmaitszych zresztą wersjach, jak hedonizm, utylitaryzm, czy nawet perfekcjonizm. Przykładem drugiego psychologizm etyczny, biologizm etyczny, socjologizm etyczny itp. Naturalizm w etyce może również przyjąć odpowiednio postać bądź metafizyki szczegółowej (np. zastąpienie etyki fillozoficzną teorią decyzji ludzkiej jako faktu psychicznego), bądź (lub) postać teorii tejże teorii. Krytykę naturalizmu podjął współcześnie na terenie W. Brytanii G. E. Moore (Principia ethica, 1903), a na kontynencie E. Husserl (Idee, 1913), M. Scheler (Formalismus in der Ethik und die materiale Wertethik, 1913), N. Hartmann (Ethik, 1925). W Polsce antynaturalistyczne stanowisko w etyce i metaetyce zajmuje T. Czeżowski oraz T. Kotarbiński. Uwidacznia się to $\mathrm{w}$ pozytywnym akcentowaniu swoistości dziedziny moralności. Swój antynaturalizm wymienieni autorzy lączą z osobliwą odmianą intuicjonistycznego empiryzmu. 
nawet po tej i innych jeszcze redukcjach, które tu już pomijamy, zbiór wyjściowy nie pozostanie pusty, owszem, w naszym nawiasie będzie nadal rojno. Więcej, dopiero teraz dostrzeżemy w nim najbardziej — z naszego punktu widzenia - interesujące przypadki ,powinienem". Będą to przypadki bezwarunkowych ,,powinienem”, tj. ,,powinienem bez względu na jakikolwiek skutek, rezultat, osiągnięcie, cokolwiek by nim nie było" ". Tytułem przykładu tylko wspomnimy znowu o tym, że właśnie to ",powinienem” kazało Sokratesowi zostać w więzieniu i potraktować swą sytuację jako sytuację „,bez wyjścia” dokładnie w tym momencie, w którym jego przyjaciele mu wyjście to zaofiarowali ${ }^{8}$ W tym właśnie znaczeniu będą te „powinienem” powinnościami bezwzględnymi, nieuwarunkowanymi, czyli nieuzależnionymi w swym charakterze powinnościowym od funkcji służebnej względem z góry acz dowolnie i swobodnie powziętych zamiarów czy celów. Jedynym celem, a zarazem racją dla tego rodzaju „powinienem”, jest obiektywnie dana wartość (godność) osoby tego, kto działa lub (i) tego, względem kogo się działa ${ }^{9}$. $\mathrm{Na}$ wartość tę zaś ani działający, ani ten, którego działanie dotyczy, nie mają najmniejszego wpływu. Jest to cel po prostu zastany i zadany, cel do zaakceptowania go dla niego samego. Nie-zaakceptowanie przysługującej mu obiektywnie wartości jest możliwe, ponieważ człowiek jest wolny. Użycie jednak wolności w taki sposób jest doświadczane jako jej nadużycie, jako sprzeniewierzenie się temu, co bezwzględnie powinne. Te „powinienem”, które aż dotąd oparły się wszelkim redukcjom, to właśnie fakty bezpośrednio dane w specyficznym przeżyciu poznawczym (choć nie tylko poznawczym), zwanym niekiedy sumieniem ${ }^{10}$. Rozpoznajemy $w$ nich i identyfikujemy auten-

7 Nie należy tego rodzaju powinności moralnej utożsamiać z jej formalistyczną interpretacją, przedstawioną w swoim czasie przęz Kanta. Trzeba jednak dodać, że gdyby oddzielić to, co jest relacją z poznanych faktów od tego, co stanowi ich interpretację $\mathrm{w}$ poszczególnych teoriach czy systemach etycznych, bylibyśmy świadkami zastanawiającej zbieżności ujęć (opisów) ze strony autorów uchodzących za „opozycyjnych" względem siebie. Por. C. S. Lewis, O etyce, w: Rozwaażnia o chrześcijaństwie, Warszawa 1969, 17-19. J. Bennet, Whatever the Consequences, „Analysis", 26 (1965-66) 83-102.

8 Por. Plato, dz. cyt., 112 i 180.

9 Alternatywę (,lub") należy tu rozumieć w znaczeniu, jakie jej nadaje logika formalna, a więc w znaczeniu, które dopuszcza również koniunkcję. Możnaby tu użyć po prostu słowa „i” (koniunkcji), gdyby nie fakt, że moje własne ,ja” jako przedmiot powinności moralnej jest w takiej samej sytuacji, jak ,ty”, „on”, „ona” itp. w drugich. Tak samo stanowi rację (jako wartość wsobna, cel dla siebie) domagającą się bezwzględnego, tj. dla niego samego, afirmowania go w odnośnych działaniach. Wówczas to własna osoba występuje zarówno w roli podmiotu jak i przedmiotu działania.

10 Sumienie jako indywidualny sad osoby o adresowanej do niej powinności postąpienia w określony sposób jest jednym tylko - jakkolwiek godnym wyróżnienia $-\mathrm{z}$ aktów bezpośredniego ujmowania poznawczego dziedpiny moralności w jej własnej specyfice (jedną z odmian doświadczenia moralności). 
tyczne, macierzyste fakty moralne ${ }^{11}$. Należy przy tym skrupulatnie odróżnić sumienie jako przeżycie poznawcze powinności bezwzględnej czynienia tego oto wobec ciebie, od samego faktu danego w tym przeżyciu, czyli po prostu odróżniać przeżycie powinności od samej powinności danej (zawsze zresztą i tylko) w przeżyciu powinności ${ }^{12}$.

\section{§ 2. FAKT MORALNY - FAKTEM DO WYJAŚNIENIA}

Nie można poprzestać na samym zarejestrowaniu i opisie faktu moralnego. Nie pozwala na to on sam wywołując samym sobą praktyczny i teoretyczny niepokój. Drugie zresztą związane ściśle z pierwszym. Po prostu potrzeba egzestencjalna praktycznego uporania się $z$ faktem bezwzględnej powinności domaga się teoretycznych par excellence rozstrzygnięć. Okazuje się bowiem, że nasze „powinienem bezwzględnie to oto wobec ciebie!" potrafią nam straszliwie doskwierać, bywają zgoła nietolerancyjne w przypadku kolizji wobec wartości, które skądinąd sobie bardzo cenimy. W wypadku konfliktu domagają się one bezwzględnie totalnego, nieokrojonego dla siebie uznania, aż do zgody na własną śmierć lub na życie, które staje się męczarnią ${ }^{13}$. A więc bardzo często moralne „powinienem” oferuje „,samozniszczenie” zamiast "samourzeczywistnienia". W tych sytuacjach trudno nie ulec pokusie zrzucenia z siebie ciężaru, jaki bezwzględna powinność moralna nakłada. A jeśli już decydujemy się go nieść, chcemy przynajmniej wiedzieć $\mathrm{i}$ to $\mathrm{w}$ możliwie najmocniejszy $\mathrm{z}$ dostępnych nam sposobów - dlaczego jest on tak bezwzględnie obowiązujący. Chcemy po prostu odpowiedzi tak uzasadnionej, by zdolna była niejako zrównoważyć lub nawet zmajoryzować ciężar, jaki powinność nakłada. Z chwilą, kiedy odnajdujemy siebie na tego rodzaju ,,rozdrożach miłości”, przestaje nam już wystarczać prosty raport sumienia: powinienem! - i odczuwamy

"1 Złożoność faktu moralnego nie stoi w opozycji do jego pierwotności. By-łoby tak jedynie wówczas, gdyby cechą definiującą pierwotność była prostoita. Fakt moralny okazuje się swoistą strukturą dynamiczną w ramach między(wewnątrz)-osobowej relacji. Próbę charakterystyki faktu moralnego zamierzamy przedstawić w najbliższym czasie.

12 Chodzi tu o różnicę pomiędzy samym aktem a jego przedmiotem, różnicę, której doniosłość przypomnieli na nowo fenomenologowie. W naszym przypadku chodzi o wyróżnienie powinności jako przedmiotu doświadczenia moralnego od przeżycia powinności jako aktu, w którym i poprzez który dana jest porwinność bezwzględna, fakt moralny.

13 Warto podkreślić dla uwydatnienia odrębności (- co zresztą nie musi oznaczać przekreślenia ścisłego związku -) porządku moralnego od porządku teleologicznego czy eudajmonistycznego. Odrębność ta istnieje nawet dla najbardziej wysublimowanej formy eudajmonizmu jaka przedstawia personalistyczny perfekcjonizm (Arystoteles, utylitaryzm agatyczny G. E. Moore'a). Różnicy tej nie widzi $\mathrm{m}$. in. S. Soldenhoff, skoro przeciwstawia eudajmonizm perfekcjonizmowi. Por. tego autora, O intuicjonizmie etycznym, Warszawa 1969, 6. 
nieprzepartą potrzebę czegoś więcej. Temu właśnie „więcej” dajemy wyraz w pytaniu: Dlaczego?, lub w pytaniu: Dlaczego w ogóle?

Odkąd to pytanie zostało postawione pod adresem faktu moralnego, fakt moralny staje się faktem do wyjaśnienia. To już nie jest proste „datum", jest to odtąd datum ad explicandum. Metodologiczna pozycja faktu moralnego ulega więc zasadniczej zmianie. Poszukiwana odpowiedź musi być oczywiście na „miarę” pytania, wyjaśnienie, racja „na miarę" zakwestionowania. Chodzi wszak o rację zdolną adekwatnie wyjaśnić fakt moralny. Gdzie tej racji szukać? ${ }^{14}$

Drogę do niej wskazuje samo zdroworozsądkowe poznanie. Na pytanie: Dlaczego to oto powinienem wobec ciebie? - odpowiada ono: Dlatego, że tylko to (tak) jest „po ludzku”; tylko to jest godne tego, do kogo twym czynem się odnosisz, i ciebie, który tym oto czynem don się odnosisz. Wszystko inne byłoby „nie-ludzkie”, „niezgodne z tym, kim jest człowiek", lub po prostu niegodne człowieka.

Spontaniczna intuicja potoczna, „ratio communis”, umiejscawia więc bezpośrednią rację faktów bezwzględnej powinności - o których bezpośrednio mówi sumienie - w tym, czym (lub kim) jest człowiek jako człowiek. Na drodze szukania adekwatnej racji dla dręczących nas w sumieniu powinności nie możemy więc pominąć jednego: wglądu w ,fenomen człowieka", w właściwą człowiekowi jako człowiekowi swoistą strukturę statyczno-dynamiczną, czyli w to, co klasyczna filozofia nazywa „naturą" Oczywiście, w tym wypadku chodzi o naturę ludzką. To już inna sprawa, czy w człowieku jako człowieku, w jego naturze, znajdziemy całą poszukiwaną odpowiedź, tj. adekwatną rację dla naszego faktu, czy też tylko rację częściową, domagającą się dla siebie dalszej jeszcze racji.

Aby to rozstrzygnąć, trzeba wrócić do naszego pytania wyjściowego i przebadać treść, zakres i charakter zamówienia poznawczego, jakie ono wyraża. Otóż pytanie: Dlaczego to oto powinienem? - zawiera w sobie dwa różne, choć nierozdzielnie związane z sobą aspekty, których zaakcentowanie sprawia, że to pozornie jedno pytanie, staje się dwoma różnymi, choć znowu wewnętrznie ze sobą związanymi pytaniami. Pytając: Dlaczego to oto bezwzględnie powinienem? - mogę bowiem pytać o treść 15: dlaczego to oto? - (dlaczego ona taka, a nie inna, dlaczego

14 Zdarza się, iż z szukania tej racji rezygnuje się (nie zawsze zresztą świadomie). Trzeba wszakże zaznaczyć, że rezygnacja ta zdaje się ignorować pytania samorzutnie powstałe na gruncie potocznego doświadczenia moralności. Jest to więc ignorowanie szeroko pojętego faktu moralnego. Wolno oczywiście ograniczyć podjęcie problematyki do pewnych tylko pytań, ale trzeba to wyraźnie zaznaczyć. W przeciwnym razie bowiem wywołuje się błędną sugestię rozwiązania całokształtu problematyki etycznej, podczas gdy w rzeczywistości rozwiązuje się jej tylko - może nie najważniejszą - część. Jest to błąd logiczny pars pro toto.

15 Dla prostoty pomijamy tu sprawę zakresu ważną skądinąd dla pełnej cha- 
tędy przebiega granica pomiędzy tym, co powinienem, a nie powinienem, między dobrem a złem?), lub mogę pytać jeszcze bardziej dogłębnie o sam fakt powinności: dlaczego powinienem? (dlaczego w ogóle jestem tak bezwzględnie czymś skrępowany, dlaczego w ogóle cokolwiek powinienem, czymkolwiek by to nie było, dlaczego raczej tak niż nie, dlaczego w ogóle tkwię i odnajduję się poznawczo $\mathrm{w}$ „,matni dobra i zła" ${ }^{16}$, a nie ,poza dobrem i złem" ${ }^{17}$, dlaczego nie wolno mi, co mi się zechce? Wszystko to są co najmniej równoważne, jeśli nie równoznaczne określenia).

Trzeba tu nadmienić, że w stosunku do obu powyższych form pytania: Dlaczego to oto powinienem? - pytanie: Co powinienem? - jawiące się bodaj równie często w kontekście sytuacji moralnych, ma charakter wyraźnie wstępny, logicznie podrzędny. Charakter ten ujawnia się najwyraźniej w tych zwłaszcza przypadkach, kiedy pytając: Dlaczego to oto powinienem? - doskonale wiemy już co powinniśmy, - że np. oddać życie, mimo to czujemy nieodpartą potrzebę dalszego pytania i nadal faktycznie pytamy: Dlaczego to, a nawet: Dlaczego w ogóle cokolwiek? Widać więc, że pytania te, wywołane praktyczną troską i teoretycznym ,zdziwieniem" wobec faktu moralnego, układają się w logiczny ciąg na zasadzie pod - czy nad-rzędności. Gdy już bowiem dysponuję odpowiedzią „to”, czy „to oto” na pytanie:

1. Co powinienem? - nie tylko mogę, ale niekiedy wprost nie potrafię nie pytać:

2. Dlaczego to (oto) powinienem? - a nawet czuć się przynaglonym do postawienia pytania jeszcze bardziej radykalnie "kwestionującego" fakt moralny, - fakt podlegania jakimkolwiek bezwzględnym powinnościom i pytać:

3. Dlaczego w ogóle to (oto, czy cokolwiek - raczej niż nic) powinienem?

\section{§ 3. NATURA JAKO RACJA FAKTU MORALNEGO}

Uświadamiając sobie dokładniej treść i charakter faktu (bezwzględna powinność czynienia tego oto wobec ciebie) i pytań z nim związanych, będziemy mogli rozstrzygnąć, czy i o ile rzeczywistość określana nazwą ,człowiek”, czyli po prostu natura ludzka, będzie w stanie dostarczyć nam poszukiwanych racji dla pytań dotyczących badanego faktu.

rakterystyki prawa naturalnego. Na ten temat por. T. Styczeń, Problem poznania prawa naturalnego, „Studia Theologica Varsaviensia”, 6 (1968, nr 1) 139.

16 Określenia z powieści J. Steinbecka „Na Wschód od Edenu”.

17 Określenia tego użył̇ F. Nietzsche jako tytułu do znanej swej książki Jenseits vom Gut und Böse. Do tego określenia nawiązują współcześni egzystencjaliści, zwłaszcza J. P. Sartre i S. de Beauvoir (etyka ambiwalencji). 
Trzeba stwierdzić, że natura ludzka nie jest - mówiąc obrazowo jednakowo uzbrojona $\mathrm{w}$ racje, po które się do niej zwracamy wyżej wymienionymi pytaniami. Najlepiej jest przygotowana do udzielania od.powiedzi na pytanie: co powinienem? Rzecz to zresztą zwyczaja, że ludzie czerpią odpowiedzi na pytanie, co powinni, z pogłębionej refleksji - odpowiedzi na pytanie: kim są, czyli przez wnikanie w sens czy sensy tego, co wykreśla specyfikę ich ludzkiej cielesno-duchowej struktury. Na tej linii umiejscawia się etyczny walor Sokratesowego: Poznaj samego siebie! - dla informowania o tym, co się powinno, co dobre dla człowieka jako człowieka, a co dla niego złe ${ }^{18}$. Na tej linii umieszcza się także rozważania na temat właściwej treści tego, co ludzkie.

O ile jednak natura jest w stanie ze swych „,własnych zasobów” niejako udzielić odpowiedzi na pytanie: co powinienem? - o tyle już zawodzi, gdy u niej szukać odpowiedzi na pytanie: dlaczego powinienem to, co powinienem, i to - jak o tym wiadomo wprost $\mathrm{z}$ raportu sumienia tak bezwzględnie! Nie wystarczy tu odwołanie się do immanentnego naturze ludzkiej pędu do rozwoju, do samourzeczywistnienia się. W tym wypadku bowiem immanentny ,zew natury” znajduje dla siebie poważnego konkurenta. Jest nim - stwierdzona również bezpośrednio - wolność człowieka. Z pozycji tej wolności „zew natury” do rozwoju, do pełnego rozkwitu, jawi się i może się jawić co najwyżej tylko jako coś do ewentualnego zaaprobowania $\mathrm{w}$ charakterze fakultatywnie uznanego celu ze strony wolnego człowieka. $\mathrm{Z}$ pozycji tejże wolności naturalna tendencja nie przedstawiałyby sobą jednak nic więcej jak tylko coś, co może - lecz bynajmniej nie musi — być przyjęte za cel dla mnie, wolnego podmiotu, co jednak jeszcze w żaden sposób nie jest mi czymś bezwzględnie zadanym. Jeżeli więc chcę mego samourzeczywistnienia, i tylko pod tym warunkiem, - powinienem w swych czynach urzeczywistniać ludzkie treści, aprobować to, co specyficznie ludzkie we mnie, w drugich. Ale jeśli tego nie zechcę, przestaje mnie wiązać cokolwiek. Tymczasem doświadczenie poucza, że sprawa ta bynajmniej nie została

18 Wypada zaznaczyć na marginesie tych rozważań, iż szukając w dynamicznej strukturze człowieka racji dla moralnych powinności postępujemy zgodnie z wymogami rozumowania redukcyjnego. Tej redukcji nie musi potem z konieczności odpowiadać progresywne rozumowanie dedukcyjne. W wyjaśnieniu faktu moralnego przechodzimy więc od ,powinien” do ,jest”, nie przechodzimy zaś, ani też nie musimy logiczno-formalnie przechodzić od ,jest” do „powinien”. Przed niemożliwością takiego przejścia przestrzegał jak wiadomo w swoim czasie D. Hume. Por. Treatise on Human Nature, III, 1, 1; por. również ks. T. Styczeń, W sprawie przejścia ou zdań orzekających do powinnościowych, „Roczniki Filozoficzne KUL”, 14 (1966, z. 2) 65-80. Osobliwości związku powinnościowych zdań etycznych z twierdzeniami wyrażającymi treść i charakter natury ludzkiej nie widzi zupełnie wielu krytyków teorii prawa naturalnego. Wskutek tego ich krytyka omija istotny problem metodologiczny tej teorii. Por. np. P. Lazari-Pawłowska, Moralność a natura ludzka, „Etyka”, 6 (1970) 9-31. To samo dotyczy umieszczonego w tym tomie artykułu „Natura ludzka a reguty postępowania” J. Wróblewskiego. 
pozostawiona fakultatywnemu uznaniu człowieka. Wymowa jego jest jednoznaczna. Przemawia ono językiem bezwzględnych, kategorycznych powinności ${ }^{19}$.

Sam ,zew natury” i jej immanentne cele nie są więc w stanie ostatecznie wyjaśnić, czyli być adekwatną racją dla faktu bezwzględnej powinności, tj. dla faktu moralnego od strony jego charakteru. Fakt ten rozważany w płaszczyźnie samej tylko natury ludzkiej jest więc nadal zagadkowy, nie wyjaśniony „do końca”. Pytanie nasze: Dlaczego w ogóle cokolwiek winienem? - nie znajduje więc dla siebie oczekiwanej odpowiedzi na linii badania czym-kim jest człowiek, na linii treści, czyli istoty bycia człowiekiem. Nie znajdujemy tu bowiem dostatecznej racji dla autorytetu, z jakim się nam uobecnia powinność moralna, jej bezwzględność. Wobec tego nie wolno nam poprzestać w szukaniu adekwatnej racji faktu moralnego na poziomie samej treści, czyli istoty lub natury człowieka, w szczególności gdy pytamy nie o samą tylko treść faktu powinności (co powinniśmy), lecz właśnie o sam ten fakt, o jego zachodzenie we właściwym mu charakterze (że bezwzględnie powinniśmy). Czy nie należy nam więc szukać wymaganej przez ten fakt racji na linii tego, jak człowiek jest? Istotnie, tutaj napotykamy na właściwy kierunek. Wprawdzie samo proste stwierdzenie przygodności człowieka nie daje jeszcze samo przez się poszukiwanego rozwiązania, poszukiwanej racji, ale już najwyraźniej pokazuje ku niej drogę. Stwierdzenie przygodności człowieka jest bowiem nie tylko stwierdzeniem niekonieczności związku tego, że człowiek jest, z tym, czym-kim człowiek jest (sens negatwny), ale równocześnie - i (na tym polega pozytwny sens przygodności) - jest stwierdzeniem koniecznej zależności niekoniecznego istnienia człowieka, a wraz $\mathrm{z}$ istnieniem wszystkiego czym-kim człowiek jest, czyli natury ludzkiej, od Absolutu Istnienia, od Boga. W Absolucie więc i koniecznym odniesieniu natury ludzkiej do Niego poprzez jej przygodne tylko istnienie, znajdujemy poszukiwaną rację dla rejestrowanego $\mathrm{w}$ sumieniu faktu bezwzględnej powinności; rację przy tym - podkreślmy to - konieczną, ponieważ jedynie uniesprzeczniającą zachodzenie tego faktu jako takiego właśnie i tak danego faktu. W świetle tej racji również i natura, z racji swej przygodności koniecznie odniesiona do Boga, nie ma już tylko czysto immanentnych celów. To, co z płaszczyzny „czystej” natury - jakby uwolnionej od istnienia ${ }^{20}$ - mogło wyglądać na jej ,immanentne cele", okazuje się teraz czymś daleko więcej. Cele natury ujawniają po prostu zamiary jej Stwórcy i tym samym uczestniczą w Jego absolutnym autorytecie. Odczytanie tych celów przez podmiot wolności nie jest już tylko odkry-

19 Por. U. Lü.ck, Das Problem der allgemeingültigen Ethik, Heidelberg 1963, 18.

20 Natura jednak ,uwolniona od istnienia” jest fikcją.

Analecta -20 
ciem ,ewentualnych i pozostawionych do fakultatywnego i swobodnego uznania szans rozwojowych", lecz odkryciem bezwzględnych zadań do wykonania, czyli dokładnie tego, cośmy w sumieniu rozpoznali jako swoiste, nieredukowalne fakty moralne.

Natura potraktowana „esencjalnie”, wyrwana z realnego kontekstu istnienia, nie tłumaczy adekwatnie faktu moralnego. Realnie dana natura człowieka jest jednak zawsze naturą w kontekście egzystencjalnej zależności od Boga-Absolutu istnienia. Dopiero też łącznie z tym egzystencjalnym kontekstem stanowi ona ,adekwatną rację" faktu bezwzględnej powinności zarówno w jego treści jak i właściwym mu charakterze. Ten wymiar zależnościowy stanowić więc musi nieodłączny warunek właściwego rozumienia i należnej interpretacji zarówno całościowego sensu ludzkiej natury, jak i poszczególnych, odkrywanych w niej sensów. Rozpatrywanie treści ludzkiej natury bez tego wymiaru jest wyrugowaniem „egzystencji ludzkiej” z jedynego miejsca w świecie, jakie ona w nim zajmuje, rozprawianiem nie o człowieku, lecz o jego iluzji. Człowiek realny to wcielona osoba a b A li o. Wszelka zatem rzetelna, zatroskana o realizm refleksja etyczna - zwłaszcza zaś mająca na celu ustalenie treści i charakteru dyrektyw moralnych — nie może się nie liczyć z tym faktem.

\section{§ 4. WEAŚCIWY SENS FAKTU MORALNEGO I JEGO RACJI: NATURY}

Natura ludzka stała się instancją zdolną do wyjaśnienia faktu bezwzględnej powinności dopiero $\mathrm{z}$ chwilą, gdy sama została poddana zabiegowi ostatecznego wyjaśnienia. Dopiero dzięki ostatecznemu jej „zakotwiczeniu" w Absolucie wiemy, czym naprawdę ona jest, i czym idąc dalej wyposażeni już w ostatecznie wyjaśniającą rację - jest naprawdę stwierdzana jako fakt bezwzględna powinność określonych czynów. Z perspektywy ostatecznej racji jesteśmy w stanie dopiero odczytać pełny, właściwy sens, zarówno faktu bezwzględnej powinności, jak i jego racji bezpośredniej: natury ludzkiej.

\section{BEZWZGLĘDNA POWINNOSĆ WEZWANIEM MIEOSCI DŌ MIEOSCI}

Egzystencjalna zależność natury ludzkiej od Absolutu oznacza totalne skierowanie statyczno-dynamicznej struktury człowieka do Boga. Znaczy to, że człowiek w tym i poprzez to, że jest i w tym i poprzez to czym jest, jest $\mathrm{k} \mathrm{u}$ B o g u. Koniecznemu uzależnieniu jego istnienia od Boga (ab Alio, a Deo), odpowiada bezwzględne „pochylenie” dynamiczne (inclinatio naturalis ad Deum) jego istoty-natury ku Bogu (ad Alium, ad: Deum) jako właściwemu sobie Aktowi, wedle miary tego, kim-czym z wol- 
nej woli Stwórcy się $\mathrm{w}$ istnieniu odnalazł ${ }^{21}$. Tą właściwą dla człowieka miarą bycia ad actum, a zarazem ad Actum (ad $A(a) c t u m$ ), jest najogólniej status bycia wcielonej osoby: tj. istoty rozumnej i wolnej, a zarazem cielesnej. Nie ma ludzkiej osoby poza ciałem, nie ma ludzkiego ciała bez osoby. Status bytowy człowieka to status wcielonej osoby, oczywiście $\mathrm{z}$ dodatkiem $a b$ Alio i z odpowiadającym temu: ad Alium jako ad suum $a(A) c t u m$. To nałożenie się na siebie treści oznaczonej wyrazami: $a b$ alio (konieczna zależność istnieniowa) oraz persona (wpisana w nią wolność) daje w rezultacie szczególny typ odniesienia człowieka do Boga jako właściwego Aktu: konieczność o charakterze bezwzględnej powinności. Tylko to bowiem jedynie uniesprzecznia bycie zarazem i przygodne $\mathrm{i}$ wolne. To bycie ku Bogu jako ku właściwemu Aktowi nie ma więc nic wspólnego z jakimś wyizolowanym byciem, które się raz stawszy zamknęło się $\mathrm{w}$ sobie (niekiedy się tak błędnie interpretuje określenie osoby jako rationalis naturae individua substantia), ale bycie, które się już stawszy wedle określonej sobie miary, wciąż pozostaje nadal i to $\mathrm{z}$ konieczności otwarte (siedlisko relacji) przede wszystkim ku Bogu i wychylone „powinnościowo" ku Niemu (Amor meus pondus meum powie św. Augustyn, a św Tomasz - bardziej ,fizycznie": appetitus, motus, inclinatio), owszem, ,pociągane" przez Niego znowu wedle miary tego czym-kim jest człowiek obdarzony wraz z nieprzerwanie udzielanym mu istnieniem ${ }^{22}$. Otóż to ,pociąganie” jest jakby wezwaniem Osoby do osoby i jest wezwaniem Miłości do miłości. Nie może być inaczej. Stwierdzono już, że na krańcach wymienionej relacji stoją osoby: Persona a Se $i$ persona ab Alio $i$ zarazem ad Alium. W związku $z$ tym trzeba stwierdzić, że tak jak od strony człowieka (a ogólniej świata) jedyną rację uniesprzeczniającą jego osobowe zaistnienie $\mathrm{i}$ istnienie jest Absolutne Istnienie Osobowego Boga, tak od strony Osobowego Boga racją tą może być tylko Miłość. Quia Deus bonus est, nos sumus, - zauważa św. Augustyn. Wszystko inne bowiem przekreślałoby status Osoby a Se, czego znów nieprzyjęcie czyniłoby z kolei absurdalnym osobowe istnienie człowieka ${ }^{23}$. Otóż $w$ tej perspektywie fakty, które się nam ja-

${ }^{21}$ Por. E. Schillebeeckx, Osobowe spotkanie z Bogiem, w: Spór o uczciwość wobec Boga, Warszawa 1966, 366.

22 Por. E. Gilson, Duch filozofii średniowiecznej, Warszawa 1958, rozdział „Miłość i jej przedmiot" (ss. 260-276) oraz aneks "Uwagi o wewnętrznej logice mistyki cysterskiej" (ss. 388-399).

${ }_{23}$ Bóg nie potrzebuje nas stwarazać, aby być sobą, tak jak my musimy byé stwarzani, by być sobą. Skoro tak, to może On stwarzać tylko z czystej samoudzielającej się, bezinteresownej i dobrotliwej milości, tylko z absolutnie pełnej wolności. Uzmanie Boga, choć z początku wywołane potrzebą uznania Go jako racji uniesprzeczniającej nasze osobowe istnienie, prowadzi do uznania Go jako osobowego Kogoś. Uznanie to potwierdzić można tylko samooddaniem. Por. J. Delanglade, Le problème de Dieu, Paris 1960, 182 i nast. oraz 247 i nast. Por. również $\mathrm{H}$. Bergson, Le deux sources de la morale et de la religion, Paris 1937, 281 oraz E. Schillebeeckx, dz. cyt., 369 i $372-373$. 
wią bezpośrednio, zwłaszcza w sumieniu, nie mogą być inne, niż $\mathrm{s}$ ą: bezwzględną powinnością spełnienia określonych czynów ${ }^{24}$. Ale $\mathrm{w}$ tej smej perspektywie nagłębszy sens tego aktu, to bezwzględna powinność odpowiedzi miłością na wezwanie Miłości ${ }^{25}$.

\section{NATURA LUDZKA JAKO PRAWO, CZYLI MIARA POWOEANIA CZEOWIEKA DO MIEOSCI}

Bezwzględna powinność spełniania określonych czynów, jawiąca się w głosie sumienia, nie jest więc li tylko anonimowym ,apelem” (appetitus naturalis, amor naturalis). Dzięki ostatecznemu wyjaśnieniu okazuje się ona osobowym wezwaniem transcendentnego „Ty” do ludzkiego „ja”, wezwaniem Miłości, owszem bezwzględnym, do zaafirmowania wolnym aktem Jego samego Wzywającego przez przyjęcie Jego wezwania. Ale kochać, odwzajemniać miłość, można tylko pod jednym warunkiem: trzeba znać treść wezwania, wiedzieć, c z e g o oczekuje wzywający. Zresztą wezwanie nie byłoby wezwaniem, a nawet w ogóle nie doszłoby do skutku, gdyby nie było określone w swej treści, gdyby nie było wezwaniem do czegoś. Wróćmy do faktu wyjściowego!

Bezwzględna powinność jawiąca się nam w sumieniu była zawsze powinnością czegoś określonego w swej treści. Wspomniano dalej, że

24 ,Sicut homo imprimit denuntiando quoddam interius principium actuum homini sibi subjecto, ita etiam Deus imprimit toti naturae principium proprium actuum", Cont. Gent., III, c. XXIV; J. de Finance na marginesie tej wypowiedzi św. 'Tomasza zauważa: „Mais il faut aller plus loin, car le commandement d'un homme ne peut, par lui même, s'intérioriser parfaitement dans celui qui le reçoit; le seul cas où l'imperium dépouille toute apparence d'une contrainte, c'est lorsqu'il procède du suprême léglislateur. Mais alors aussi la loi promulguée dans la conscience coincide avec l'inclination imprimée dans la nature. C'est l'expérience du devoir qui permet la connaissance la plus profonde du dynamisme naturel". Można by tu dodać, że doświadczenie powinności moralnej jest jedyną w swym rodzaju okazją poznania ,od wewnątrz" bezwzględnego wezwania (imperium) Boła w stosunku do świata (człowieka), tak jak doświadczenie własnego sprawstwa jest w odnośnej dziedzinie jedyną okazją wglądu „od wewnątrz" w istotę działania przyczynowo-sprawczego. Por. J. de Finance, Être et agir dans la philosophie de Saint Thomas, Roma 1960, 184.

${ }_{25}$ Sądzić, iż dlatego, że człowiek z konieczości kocha samego siebie, nie zdoła kochać Boga milością bezinteresowna, znaczy zapominać, że kochanie Boga miłością bezinteresowną jest dla człowieka jedynym prawdziwym sposobem kochania samego siebie. Wszystkie tkwiące w nim pierwiastki miłości własnej odróżniają go jeszcze od tej miłości, którą jest Bóg. Wszystka poniechana przezeń miłość siebie do siebie upodabnia go do Boga, czyniąc go tym samym bardziej podobnym do siebie. Człowiek będąc (ontycznie) obrazem, im bardziej jest odpodobniony, tym mniej istnieje, a im bardziej jest upodobniony (do swego wzoru), tym więcej jest sobą. Istnienie więc polega dla niego na możliwie najmniejszym odróżnianiu się, a kochanie siebie polega na możliwie najzupełniejszym zapomnieniu o sobie. ...Skoro bowiem człowiek jest obrazem Boga, to im bardziej będzie się upodabniał do Niego, tym bardziej będzie urzeczywistnial swą własną istotę. Bóg zaś jest doskonałością bytu, zna siebie dogłebnie, a kocha - bez reszty. Ażeby człowiei mógł w pełni urzeczywistnić te wirtualne możliwości i stać sie integralnie sobą, musi się stać tym doskonałym obrazem Boga: miłością Boga do Boga. Zob. Gilson, dz. cyt., 276 . 
treść poszczególnych „,powinienem” czerpała dla siebie bezpośrednie oparcie w treści tego czym-kim jestem, w naturze ludzkiej. Owszem pokazano, że na płaszczyźnie treści, ,tego co", natura ludzka jest właściwą racją tłumaczącą fakt moralny w odnośnym aspekcie. Jeśli jednak, jak pokazano, jestem tym, czym-kim jestem, czyli w mej własnej naturze dlatego, że $\mathrm{w}$ ogóle jestem, jestem zaś nie dzięki samemu sobie, to $\mathrm{w}$ takim razie tylko Ten, który z miłości obdarzył mnie istnieniem, obdarzył mnie również moją naturą. Ostatecznie więc On sam też poprzez danie mi ludzkiej natury i usytuowanie jej w stworzonym przez Siebie świecie wypisuje każdorazowo treść poszczególnych wezwań do mnie ${ }^{26}$.

$\mathrm{W}$ tej to ostatecznościowej perspektywie odsłania się więc dopiero właścwy sens i rola natury ludzkiej w kontekście moralnego działania człowieka. Natura okazuje się mową Boga do człowieka, Jego językiem, słowem. Owszem, stanowi ona - chodzi oczywiście o czysto naturalny punkt widzenia - jedyną instancję, poprzez którą Bóg komunikuje człowiekowi treść tego, czego od niego oczekuje. Tak jak przygodne istnienie człowieka tłumaczyło nam fakt, że człowiek jest w ogóle wezwany, tak związana z jego istnieniem ,miara” bytu: natura, tłumaczy, do czego Bóg człowieka wzywa. Wpisując w naturę treść swego oczekiwania pod adresem człoweka, Bóg tym samym określił kształt poszczególnych odpowiedzi na Jego wezwania. Jedynie więc $z$ tego rezerwuaru Boskiego zamówienia, czyli ze swej natury, może człowiek odczytać zarówno kształt poszczególnych wezwań Miłości do miłości, jak i ogólny kształt swego całościowego, życiowego powołania do miłości.

I podobnie jak wyżej nie umieliśmy sobie wytłumaczyć autorytetu i mocy bezwzględnej powinności (faktu) samym tylko ,,apelem natury" - zabrakło jej bowiem dostatecznego ku temu autorytetu - i dopiero transcendentna $\mathrm{w}$ stosunku do niej proweniencja tej powinności wyjaśniła i uprawomocniła wyjątkowy jej prestiż, tak i tu, na płaszczyźnie treści, zauważamy, że towarzyszący jej autorytet, pochodzi nie tyle stąd, że jest ona $z$ mojej natury po prostu, lecz raczej stąd, że jest z mojej natury jako mi z szczodrości Absolutu udzielanej. Ostateczne źródło autorytetu tej treści jest więc identyczne z ostatecznym źródłem samej treści. Własny porządek natury wykreślający bezpośrednio i obiektywnie we mnie i dla mnie treść bożych wezwań, będąc sobą wyłącznie dzięki nieustannemu stwarzaniu natury, jest tym samym nieustannie ustanawiany i określany w tym, czym jest, przez stwórczy zamiar Boga. Jest więc natura zarazem czymś normującym i czymś normowanym, regulującym i regulowanym. Owszem, normuje postępowanie człowieka o tyle, o ile sama jest normowana przez odwieczny a zarazem wciela-

26 Por. J. de Finance, nr cyt. 
jący się $\mathrm{w}$ czasie $\mathrm{w}$ nią zamysł stwórczy Boga. Z konieczności regulata i mensurata - jak wszystko, co przygodnie istnieje - przez Stwórcę, sama $\mathrm{z}$ kolei staje się regulans et mensurans stanowiąc zobiektywizowane siedlisko sensów-zamiarów Boga uprzednich w stosunku do sumienia jako „rozumu w akcji”, a więc rozumu jako instancji zdolnej do odczytania tych sensów i przekazania ich jako bożych zamiarów do zaafirmowania wolną aktywnością człowieka. W tym właśnie znaczeniu natura jako siedlisko bożych zamiarów względem człowieka i jego wolnego działania staje się we właściwy dla siebie tylko sposób prawem moralnym niepisanym, czyli tzw. prawem naturalnym. Jak jednak z powyższego widać, znaczenie tego prawa - wbrew wszelkim legalistycznym jego interpretacjom - polega na odsłanianiu zdeponowanej w mej własnej naturze treści tego, czego Bóg oczekuje ode mnie, a więc na umożliwieniu mi osobowego $\mathrm{z}$ Nim spotkania $\mathrm{w}$ akcie odpowiedzi na Jego wezwanie, w akcie miłości. Natura pełniąc rolę przekaźnika zamysłów Boga względem człowieka ma więc w sobie piętno czegoś sakralnego: stanowi zobiektywizowany $w$ fizyczno-duchowej strukturze człowieka zespół sensów, czyli język, którym sam święty Bóg, Bóg miłości, zwraca się do człowieka. Stąd też określenie prawa naturalnego: ordinatio divini intellectus ad bonum hominis. Przez to też sama natura stanowi przedmiotową prawdę, wiążącą nieodwołalnie do jej uznania umysł zdolny ją rozpoznać. W tym sensie też stworzona natura człowieka - a poprzez jej odczytanie rozum człowieka, zwłaszcza sumienie, - uczestniczy w odwiecznej prawdzie zamysłów Boga względem człowieka. Stąd bierze dla siebie podstawę klasyczne określenie prawa naturalnego jako participatio legis aeternae in creatura rationali ${ }^{27}$.

Kategoria natury i rozumianego, jak wyżej, prawa naturalnego jest nam tedy nieodzowna - w charakterze racji koniecznej - dla ostatecznego wyjaśnienia faktu bezwzględnej powinności określonych działań w aspekcie jego treści, a więc w aspekcie, bez którego fakt ten nie byłby sobą. Licząc się z tym faktem, nie możemy nie przyjąc adekwatnej dla niego, tj. jedynie uniesprzeczniającej go racji. Oto, dlaczego nie możemy się obejść bez natury i prawa naturalnego. Przyjęcie tych kategorii okazuje się po prostu wyrazem szacunku wobec faktów, a więc wyrazem postawy rzetelnego realizmu i empiryzmu w myśleniu o człowieku, i najbardziej dotyczących go sprawach.

\section{§ 5. O PEWNYCH KONSEKWENCJACH NEGACJI PRAWA NATURALNEGO}

Natura jest nam tedy nieodzowna $\mathrm{z}$ tytułu jej roli jako jedynego pośrednika przekazywania treści wezwań transcendentnego „Ty" ludz-

27 Sw. Tomasz przytacza je za św. Augustynem, Summa theol. I-II, 91, 2. 
kiemu „ja”. Jest to, jak widzieliśmy, rola zasadnicza, istotna co do określenia charakteru wzajemnego kontaktu obu korelatów, jak i - bardziej jeszcze podstawowo - dla ukonstytuowania samego tego kontaktu. Zacznijmy od drugiego.

$1^{\circ}$ Zauważmy, że negacja możliwości odczytania treści bożych wezwań do człowieka z natury (ze świata, którym i w którym obiektywnie jest człowiek) ${ }^{28}$ prowadzić musi do uznania samych wezwań za beztretościowe. Ale wezwania, które nic nie komunikują, stają się bezprzedmiotowe, puste. Po prostu przestają w ogóle być sobą. Obstawać więc przy wezwaniach beztreściowych: „Bóg wzywa, ale nie mówi w żaden sposób do czego" - to obstawać przy pozycji absurdalnej. Takie wezwania nie mogłyby dojść do skutku. One jednak są faktem. Rejestruje je sumienie jako bezwzględną powinność spełniania określonych w swej treści czynów. Skoro te fakty mają miejsce, jedynie rzetelną wobec nich postawą jest je uznać $z$ całym inwentarzem uniesprzeczniających je racji, a więc wraz $\mathrm{z}$ naturą jako daną razem $\mathrm{z}$ istnieniem człowiekowi przez Absolut Istnienia i Miłości. Nie podobna więc wyeliminować natury, jeśli nie chce się zignorować samego faktu. Albowiem nie przyjąć go w całości, lecz w okrojeniu (wezwanie, ale bez treści) jest koniec końców ignorowaniem samego faktu. Sprawą tedy pierwszorzędnej wagi staje się tu nie to, czy uznawać czy nie uznawać prawo naturalne, ale to, czy wolno nam czy nie ignorować określone fakty.28a

$2^{\circ}$ Bez pośrednictwa natury nie umiemy się dalej obejść, jeśli chcemy ocalić samą możliwość człowiekowi miłowania Boga. Warunkiem miłowania drugiego jest dotarcie do tego, czego ten drugi pragnie, czego od nas oczekuje. Tym bardziej, jeśli tym drugim jest święty w „swych pragnieniach i oczekiwaniach” Bóg. Można Go kochać odpowiadając na Jego tylko wezwania. On Sam musi być ich miarą, jeśli odpowiedź na nie, ma być odpowiedzią Bogu a nie sobie. Otóż, jeśli przekreślimy przekaźnik natury, przekreślamy jedyną możliwość dowiedzenia się, czego naprawdę Bóg od nas oczekuje, rozpoznania treści Jego wezwania, a więc i możliwość udzielania na nie odpowiedzi, czyli możliwość aktu miłości. Jak bowiem odpowiadać, skoro się nie

28 Por. uwagi R. Ingardena na temat twierdzenia, że „być” dla człowieka to tyle, co „być w świecie”, Z badań nad filozofia wspótczesna, Warszawa 1963, 359; por. również J. B. Metz, Leiblichkeit, w: Handbuch theologischer Grundbegriffe, München 1963, t. II, 31-37; R. le Trocker, Kim jestem ja - człowiek?, Paris 1968, 25-47; K. Rahner, Schriften zur Theologie, Einsiedeln-Zürich-Köln 1962, t. IV, $304-311$.

28a Nie trudno wykazać, że z podobnymi trudnościami musi się liczyć ewolucyjna koncepcja „prawa natury o zmiennej treści”. Nie ma w niej bowiem miejsca na doświadczenie jakiejkolwiek treści o charakterze bezwzględnym. Tymozasem doświadczenie to jest faktem. or. E. Coreth, Was ist die philosophische Anthropologie? „,Zeitschrift für Kath. Theologie”, 91 (1969) 266-267). 
wie, o ca się jest pytanym, jak odpowiadać na wezwanie Boga, skoro się nie wie, do czego się jest przez Niego wzywanym, czego On sam od nas oczekuje? Paweł pod Damaszkiem doskonale wiedział, co jest dlań nieodzowne, by jego odpowiedź była naprawdę, a nie z pozoru tylko jak dotąd - odpowiedzią Bogu, czyli odpowiedzią miłości. Stąd pytanie: „Panie, co chcesz, abym czynił?’ Wiedział té̇, że ludzie pozbawieni objawienia i nie mogący ,w swych sercach" w naturalny sposób odczytać treści zamysłów bożych względem nich, byliby pozbawieni wszelkiej możności odpowiadania Bogu na Jego wezwania i tym samym wolni od wszelkiej odpowiedzialności wobec Niego, bo ,wolni” od wszelkiego kontaktu z Nim ${ }^{29}$.

Przekreślając pośrednictwo natury w przekazywaniu treści wezwań Boga miłości, tym samym uniemożliwia się wszelkie bosko-ludzkie commercium, wszelki , dialog z Bogiem” w ogóle. Język bowiem Boga w żaden już sposób nie dosięga człowieka. Po usunięciu realistycznego pojęcia natury propozycje tych, którzy mimo to chcą jeszcze mówić o możliwości naturalnej miłości Boga ${ }^{30}$, noszą znamię czysto postulatywnych deklaracji. Wszystko też, co w miejsce natury jako przekaźnika bożych sensów, zaproponowano, wydaje się wysoce nieudane. Do rzędu tych nieudanych rozwiązań należy zaliczyć idealistyczną w istocie propozycję, wedle której samo wezwanie pochodzi co prawda od Boga, ale człowiek, jego aktywna świadomość, wypełnia je treścią. W miejsce Sinnerkenntnis proponuje się Sinngebung (F. Böckle) ${ }^{31}$. Jeśli jednak stwarzana poznawczo

29 Por. Rz 1, 19-20 oraz 2, 14-15.

30 Zwłaszcza w odniesieniu do tzw. ,anonimowych chrześcijan”.

31 Realistyczne pojęcie natury dopuszcza jedynie takie rozumienie ,nadawania sensu" (Sinngebung), które polega na aktywnym afirmowaniu i angażującym wolność urzeczywistnianiu sensów zdeponowanych przez Boga w naturze. Odnośną intuicję trafnie wyraża D. Hammarskjöld: „Każda czynność - to przedłużony akt stwónczy, akt świadomy, bo masz odpowiedzialność człowieka; ale akt kierowany spoza granic świadomości przez tę Moc, która człowieka stworzyła; jesteś wolny od rzeczy, ale spotykasz się z nimi w doznaniu, które ma w sobie wyzwalającą czystość i charakterystyczną ostrość objawienia. Dlatego - w świetle wiary, jako ,zaślubin Boga z duszą" - wszystko ma sens. Tak żyć, tak używać tego, co ci do rąk dano...". Zob. Drogowskazy, Kraków 1967, 121. Koncepcja Sinngebung wydaje się próbą przeszczepienia na grunt teorii prawa naturalnego pojęcia powstałego w systemie myślowym, który programowo wyklucza pojęcie natury i konsekwentnie pojęcie prawa naturalnego. „Człowiek, tak jak go pojmuje egzystencjalizm - pisze J. P. Sartre - nie może być określony, gdyż na początku jest niczym. Będzie dopiero potem i będzie taki, jakim uczyni sam siebie. A więc nie ma natury ludzkiej, bo nie ma Boga, który by ją określił. Człowiek jest nie tylko taki, jakim sie pojmuje, ale także taki, jakim pragnie być. Zob. Existentialisme est un humanisme, 12, cyt. za R. Coffy, Bóg niewierzacych, Paris 1968, 65. Konsekwencja Sartre'a wydaje się nam goidną naśladowania i zalecenia. Jeśli zatem ktoś chce podzielać jego konkluzje, winien być gotów przyjąć jego przesłanki. Por. E. L. Mascall, Chrześcijańska koncepcja człowieka, Warszawa 1962, 36. Myśli o aktywnym afirmowaniu sensów zdeponowanych przez Boga w naturze nie można jednak publicystycznie splycać. Por. S. Grygiel, Ludzka twarz prawa natury, 175 ,Znak" (1969) 16. 
przeze mnie samego treść ma wypełniać wezwanie, to czy wezwanie jest w ogóle wezwaniem, a tym bardziej wezwaniem Boga? Czy tu jeszcze człowiek wsłuchuje się $w$ głos Boga czy też słyszy już tylko siebie i zamyka się w swym własnym kręgu, w którym nie ma miejsca na transcendencję, na ekstazę, na „wyjście z siebie” i wejście w krąg „,języka" Boga. Z człowieka, jako absolutu świadomości wyprowadzającej z siebie treści, nie ma już wejścia w sferę ,,języka” jakiegoś ,alter ego”, nie ma miejsca nie tylko na prawo naturalne, lecz nawet na to, co by można było zasadnie nazwać dialogiem. Pozostaje jedynie monolog rozpisany co najwyżej przez człowieka na dwie role lub „dialog głuchych". Zamiast dialogu z Bogiem i wsłuchiwania się w Jego język, jest tylko słuchanie własnego bełkotu pod pozorem słuchania Boga. Wówczas możliwe jest wszystko inne - oczywiście w teorii - np. niczym nieograniczona ekspansja człowieka, jego samourzeczywistnienie do granic absolutu, ale niemożliwe jest jedno: miłość ${ }^{32}$. Zburzono bowiem jedyny most porozumienia się dla Boskiego i ludzkiego „Ty" i ,,ja" - ich związek koniecznościowy $\mathrm{z}$ racji zależności $\mathrm{w}$ istnieñiu $\mathrm{i}$ daną jedynie $\mathrm{w}$ jego ramach naturę. W wyniku tego droga do autentycznego spotkania z Bogiem i miłowania Boga przez człowieka zostaje - przynajmniej w płaszczyźnie naturalnej - nieodwołalnie zamknięta ${ }^{33}$.

I jeszcze jedna trudność tego stanowiska. Jeśli moja treść wypełnia wezwanie, to już tylko mój autorytet stać może za nim. Co jednak począć $z$ faktem bezwzględnej powinności i $z$ autorytetem, jaki faktycznie stoi za moralną powinnością? Fakt ten zostaje tu znowu zignorowany, pozostawiony na boku bez wyjaśnienia. Znowu więc wypada nam stwierdzić: nie jest to rzetelne myślenie empiryczne i realistyczne, którego kanonem jest: $1^{\circ}$ - uznawać fakty, tak jak są dane i $2^{\circ}-$ do końca je wyjaśniać. Teorie zatrzymujące nazwę prawa naturalnego, które od tego odstępują i pozwalają sobie na ignorowanie faktów, objawiają

32 Krytyka ujawniła beznadziejność prób Sartre'a podejmowanych dla uzasadnienia transcendencji (dépassement de soi, ekstaza). Jeżeli akt negacji siebie, tj. akt negacji treści wyłanianych przez podmiot poznania ma mieć w ogóle jakieś uzasadnienie, tj. nie być bez powodu oraz jeśli uzasadnienia tego z racji systemowych nie można szukać w obiektywnej wartości kogoś poza sobą miłowanego dla niego samego (racja zapomnienia o sobie), to uzasadnienie to można znaleźć jedynie w afirmacji swego ,,ja”. Sartre'owti pozostaje więc wybór pomiedzy ,absurdem" lub „zamknięciem się w sobie”. Nic dziwnego, że Sartre stał się filozofem „złej wiary”.

33 Ma to - na szczęście - miejsce jedynie w teorii, w dodatku fałszywej. Trudno tu jednak nie wyrazić zdziwienia wobec prób przyswajania teologii chrześcijañskiej Heideggerowskiej czy Sartre'owskiej koncepcji człowieka jako absolutu świadomości i wolności, skoro sami jej autorzy uważaja ją za możliwą jedynie przy założeniu ateizmu. Niemniejszy sprzeciw należy założyć przeciw wspomnianym próbom z racji nieliczenia się tej koncepcji z wymaganiami zdroworozsądkowego realizmu w myśleniu o człowieku. A przecieź realizm ten jest nie tylko podstawa filozoficznej teorii człowieka, ale również jedną z podstawowych tez objawienia chrześcijańskiego. Credo in unum Deum... Creatorem... visibilium et invisibilium. 
symptom niepokojącego kryzysu. Kryzys ten nie dotyka jednak bynajmniej samego prawa naturalnego. Jest to raczej kryzys $\mathrm{w}$ myśleniu o nim, a ogólniej kryzys w zakresie metodologii wiedzy filozoficznej o tym, co realne i realne dane ${ }^{34}$..

\section{§ 6. ROZUM - SUMIENIE A PRAWO NATURALNE}

Okoliczność, że rozum: (świadomość) sam w sobie nie znajduje dość autorytetu, by wyjaśnić nam bezwzględny charakter powinności moralnej, że raczej staje wobec niej bezradny jako wobec czegoś, co po prostu musi uznać i uznawszy szukać poza swą własną aktywnością wyjaśnienia dla tego faktu, otóż ta okoliczność od innej tylko strony potwierdza obiektywny, transsubiektywny (chodzi o podmiot poznania!) charakter powinności moralnej i transsubiektywną proweniencję jej charakteru. Rozum zatem o tyle tylko jest instancją normującą, o ile wnikając w naturę jako we właściwe siedlisko sensów-zamierzeń Stwórczej Miłości względem człowieka wiąże się obiektywną prawdą tych sensów. Właściwa więc funkcja rozumu - i na tym polega jego udział w realizacji powołania do miłości - polega na wyczytywaniu (intellectus) sensów immanentnie tkwiących $\mathrm{w}$ naturze jako zamiarów Boga względem człowieka $i$ ich prawdy immanentnej naturze jako prawdy $\mathrm{w}$ gruncie rzeczy transcendentnej, czyli prawdy odwiecznych zamysłów miłości Boga wcielonych $\mathrm{w}$ jego czasową naturę, prawdy, która sama sobą wymusza dla siebie intelektualne uznanie i domaga się następnie totalnego dla siebie zaafirmowania osobowym zaangażowaniem: wolnym czynem. Tak jak funkcją rozumu nie jest tworzenie sensów przedmiotów, lecz ich rozpoznawanie, tak też nie jest funkcją rozumu tworzenie prawdy, lecz jej odczytywanie i uznawanie, nie tworzenie prawa, lecz odczytywanie prawa, nie tworzenie projektu człowieka, lecz wyczytywanie go z pokładów przydzielonej mu cielesno-duchowej struktury od Boga. Natura człowieka nie jest więc względem rozumu i wolnej aktywności człowieka czymś w rodzaju bezkształtnego tworzywa, „materia artis" 35 - jak w sztuce - gdzie właśnie ,natura” stanowi li tylko two-

34 Odpowiednio do tego należałoby raczej wyrazić niepokój w odniesieniu do stopnia metodologicznej dojrzałości niektórych spośród uprawiających teorię prawa naturalnego. Por. moje uwagi na marginesie międzynarodowego spotkania teoretyków prawa w Salzburgu w 1962 r. w cytowanym już wyżej artykule, „Problem poznania prawa naturalnego", 122-139. Brak przedstawienia trafnej diagnozy metateoretycznej własnej dyscypliny, ze strony teoretyków prawa naturalnego i etyków wystawia na łatwą choć pozorną w gruncie rzeczy krytykę teorii prawa naturalnego. Por. przyp. 18.

34a Por. J. Pieper, Fortitude and Temperance, Brooklyn 1954, rozdz. Nature of Prudence.

35 Por. A. Arntz, Prawo naturalne $i$ jego dzieje, „Concilium”, (Poznań-Warszawa 1968), $1-10(1965 / 6) 370$. Por. również przypis 31 . 
rzywo nieuformowane, któremu człowiek wedle własnej inwencji nadaje sens i wciela w nie swe własne pomysły-projekty wedle upodobania. Przypisywać coś podobnego człowiekowi i jego rozumowi w zakresie jego aktywności moralnej, to deifikować człowieka, przypisywać mu kompetencje Stwórcy, w gruncie rzeczy zaś służyć destrukcji moralności, lub co na jedno wychodzi, destrukcji człowieczeństwa w człowieku. Nade wszystko jest to jednak znowu ignorowanie faktów danych sumieniu: bezwzględnej powinności spełniania określonych czynów czy równorzędnych z tym konstatacji ukazujących sytuację człowieka jako sytuację „wolności pod prawem”, „odpowiedzialnej wolności”, czy też sytuację „matni dobra i zła", nigdy zaś ${ }^{36}$ jako sytuację „poza dobrem i złem" 37 .

Jeśli prawda mych przeznaczeń, mego powołania jest wpleciona $\mathrm{w}$ to, czym i ku czemu obiektywnie jestem, w realnie przydzieloną mi wraz $\mathrm{z}$ istnieniem naturę, to naczelnym zadaniem rozumu jest jej odczytywanie i kierowanie aktywnością człowieka w jej urzeczywistnianiu i tym samym nadawaniu zamiarom bożym względem mnie realnych kształtów. To wolne włączenie się w nurt zamysłów bożych względem człowieka - rozpoznawanych przez rozum - to ludzka forma odpowiadania miłością na miłość, to jedynie też dostępna człowiekowi możliwość afirmowania Boga w nim samym ze względu na Niego oraz drugich i siebie ze względu na Niego. Dzieje miłowania Boga wedle miary przez Niego podanej to jedynie prawdziwe dzieje, jedyna historia godna człowieka.

$\mathrm{Na}$,czytaniu prawdy o człowieku” w naturze nie wyczerpuje się jednak rola rozumu $\mathrm{w}$ kontekście natury. i prawa naturalnego. Nie powiedzieliśmy jeszcze czegoś bardzo ważnego. Otóż tak, jak od strony Boga natura jest jedyną instancją, poprzez której nieustanne stwarzanie Bóg nieprzerwanie wciela w nasz ludzki świat, swój odwieczny zamiar względem nas ${ }^{38}$, tak też na odwrót, od mojej strony, mój rozum urasta do rangi jedynej instancji zdolnej do odczytania i objawienia mi jako

36 Wyłączając podyktowane wymogami dogmatycznie przyjętej doktryny urojenia niektórych filozofów na temat moralności. G. Manser, Das Naturrecht in thomistischer Beleuchtung, Freiburg 1944, 53-55 oraz C. I. Lewis, Poznanie, dziatanie $i$ wartościowanie, w: Filozofia amerykańska, Boston 1958, 213; B. Schüller: Gesetz und Freiheit, Düsseldorf 1966.

37 To zrozumiałe, że koncepcja Sinngebung umiejscawiając człowieka poza rzeczywiście przysługującą mu pozycją w całokształcie rzeczywistości, umiejscawia go także ,poza dobrem i złem".

38 W ramach planu właściwego każdemu człowiekowi z racji jego człowieczeństwa (persona incarnata ab Alio et ad $A(a)$ lium sicut ad suum $A(a)$ ctum) jest oczywiście miejsice na realizację niemniej moralnego w swym charakterze zadania indywidualnego z tytułu jedyności i niepowtarzalności każdej osoby ludzkiej. Jest to jednak mimo wszystko niepowtarzalność kogoś z ludzi, kogoś z ich wspólnoty. Por. J. Goffinet, Morale de situation et morale chrétienne, Bruxelles 1963, 69 i nast. 
podmiotowi wolnego działania - bożych zamysłów zdeponowanych w naturze. To jego nieodstępna i niezbywalna rola, nic go w tym nie wyręczy. On jest jedyną - na mój własny użytek — instancją, odsłaniającą obiektywny sens bożego języka, zawarty w pokładach mej własnej natury. Nie ma też innego sposobu dowiedzenia się tego, czego Bóg ode mnie chce, jak tylko poprzez ,zapuszczenie sondy” mego rozumu w moją naturę. Nawet jeśli inni chcą mi usłużyć własnymi rozpoznaniami ludzkiej natury $w$ tym zakresie, w jakim ją ludzie wspólnie między sobą dzielą, to i wtedy treść ich komunikatów nie może mnie „chwycić” inaczej, jak tylko poprzez moje jej rozeznanie.

Ze względu więc na $1^{\circ}$ bezwzględną powinność respektowania sensów wcielonych w naturę jako bożych zamiarów i $2^{\circ}$ ze względu na jedyność narzędzia docierania do nich, jakim jest rozum, człowiek nie ma innego sposobu uzgadniania wolnego działania i obiektywizowania własnej postawy wedle prawdy bożych zamysłów, jak tylko ten jeden: uznać je i respektować je w tym wydaniu, w jakim mu je przedstawi i ukaże to jedno jedyne narzędzie informacji: jego własny rozum, lub jak mówimy w tym kontekście: jego własne sumienie. Jest ono bowiem jedynym dla konkretnego człowieka przekaźnikiem, przez który może się przedostać do człowieka prawda bożych zamysłów zawartych w naturze. Na tej prawidłowości opiera się też ostatecznie bezwzględny obowiązek człowieka respektowania zawsze sądów własnego sumienia. Słuchać sumienia bowiem, to dla człowieka jedyny sposób słuchania Boga. $\mathrm{Na}$ tym zresztą zasadza się także tzw. prawo do wolności sumienia, czyli uprawnienie do tego, by mi nikt nie przeszkadzał w obowiązku wierności względem widzianej przeze mnie prawdy działania. Wszystko to utrzymuje się w mocy dlatego, że sumienie nie będąc twórcą, lecz tylko przekaźnikiem prawdy, jest mimo to jej przekaźnikiem dla mnie jedynym.

Czy wobec tego idąc za głosem prawdy przekazywanej przez sumienie, człowiek zawsze idzie za prawdą? Czy słuchając sumienia człowiek zawsze słyszy Boga, Jego prawdę? Byłoby tak tylko wówczas, gdyby rozum-sumienie było idealnym narzędziem informacji, a więc gdyby zawsze bezbłędnie wnikało w prawdę zamysłów Boga, wcielonych w naturę. Tak jednak - jak wiemy - nie jest. Nie mało razy zdarzyło się nam, że byliśmy czegoś niezachwianie pewni, co potem, przy pogłębionym, udoskonalonym rozpoznaniu, okazało się pomyłką ${ }^{39}$.

W sytuacji więc, kiedy człowiek świadom jest, jak bardzo niedosko-

39 Już samo to starczyłoby do odrzucenia jako błędnego poglądu, zgodnie z którym sumienie stanowi instancję ostatecznie rozstrzygająca o prawdzie (słuszności) czynu. Przypadki stwierdzenia błędów i pomyłek objawiają rozumowi jego własną niedoskonałość i potrzebę ciągłego doskonalenia jego rozpoznań. Por. B. Pascal, Myśli, Warszawa b.r.w., wyd. III, 31, 248-249. 
nałym jest to narzędzie, poprzez które dochodzi doń tak ważkie dla niego orędzie, już sama naturalna mądrość zobowiązuje go do maksymalnej troski o zagwarantowanie sumieniu właściwego funkcjonowania, aby tym sposobem zapewnić rzetelność jego informacjom. Troska ta każe rozciągnąc nieustającą kontrolę na podawane przez sumienie diagnozy i rozpoznania oraz zająć postawę gotowości na pouczenie w sprawach moralnych (Arystotelesowska docilitas), zwłaszcza gdy pochodzi ono od kogoś, kto uwierzytelnił się skądinąd jako ,ekspert moralności" 40.

Wobec powyższego, obowiązkowi bezwzględnego respektowania sądów własnego sumienia towarzyszyć będzie równie bezwzględny obowiązek jego kontroli. Jeden i drugi zresztą jest pochodną bezwzględności, z jaką się nam uobecnia wprost rzeczywistość moralna ${ }^{41}$. Można to wyrazić jeszcze w taki sposób, że na prawie wolności sumienia jako objawicielu prawa naturalnego ciąży serwitut odpowiedzialności za autentyczność i rzetelność jego informacji. Mamy nienaruszalne prawo słuchania własnego sumienia, ale też jesteśmy obciążeni obowiązkiem odpowiedzialności za to, jakiego sumienia słuchamy: czy przekazującego obiektywną prawdę zamysłów Boga względem nas, czy też tylko jej pozory.

\section{§ 7. REALIZM - PODSTAWA POJECIA PRAWA NATURALNEGO}

Tak oto rysuje się wewnętrzna architektonika koncepcji prawa naturalnego. Składają się na nią trzy niejako kondygnacje. Dwie skrajn̊ wiąże z sobą i zespala kondygnacja środkowa. Jest nią integralnie ujęta natura ludzka jako persona incarnata $a b$ Alio et ad A(a)lium sicut ad suum $A(a) c t u m$. Jest to coś, co Bóg jako Miłość Stwórcza daje i zarazem coś, co człowiek w sobie jako siebie przy pomocy rozumu (sumienia) odkrywa jako dar, a zarazem jako zobowiązujące go bezwzględnie wezwanie. Rola kondygnacji skrajnych przedstawia się odmiennie w zależności od tego, czy na tę strukturę spojrzymy z punktu widzenia zależności w bytowaniu czy też z punktu widzenia zależności w poznaniu.

$40 \mathrm{Na}$ kartach Etyki Nikomachejskiej raz po raz jawi się w roli dodatkowej instacji określającej słuszny sposób zachowania się, sposób charakteryzujący postępowanlie dobrego człowieka (Np. I 8. 1099 a 13). Domyślamy się tu wplywu, jaki na Platona i jego uczniów - wywierała indywidualność i autorytet moralny Sokratesá.

41 I w tym przypadku rozróżnienie aktu i jego przedmiotu oddaje swoje usługi. In actu exercito dana jest nam wprost jako przedmiot bezwzględna powinność moralna określonych postąpień. Akt sumienia jest jedynie id quo, czyli nie ,uprzedmiotawia się" nam pełniąc rolę prezentowania poznawczego swego przedmiotu. Dopiero akt stwierdzenia omyłek skierowuje naszą uwagę poznawczą na nie i na jego rolę. Wówczas te $\dot{z}$ in a ctu signato zaczynamy widzieć i interesować się jego funkcją oraz nakładać na nią ,zobowiązania" wynikające z jego funkcji służebnej w stosunku do takiego przedmiotu, jak bezwzględna powinność moralna. 
$\mathrm{Z}$ punktu widzenia ujawnionej przyczynowej zależności (in ordine essendi) kondygnacją pierwszą i podstawową zarazem będzie Bóg jako przez akt stwórczej miłości inicjujący cały ów porządek. Będzie to prawo naturalne ante naturam, lub - jak mawiali klasyczni moraliści filozofowie i teologowie - prawo wieczne (lex aeterna). Kondygnacją środkową będzie oczywiście sam postawiony w bycie, istniejący człowiek $\mathrm{z}$ właściwą mu wyżej określoną naturą. Jest to prawo naturalne $\mathrm{w}$ sensie jak najbardziej właściwym i obiektywnym, in natura. Ten właśnie sens św. Tomasz wyrażał określeniem participatio legis aeternae in creatura rationali. Wreszcie kondygnację ostatnią, dopełniającą, stanowi świadomościowy obraz obiektywnego prawa naturalnego dany $\mathrm{w}$ odpowiednich aktach poznania, przede wszystkim $\mathrm{w}$ aktach sumienia, poprzez które człowiek odkrywa niejako samego siebie jako bezwzględne zadanie dla siebie (wobec innych, siebie). Ono to właśnie w wyniku ostatecznie wyjaśniającej refleksji okazuje się wezwaniem Miłości do miłości ${ }^{42}$. Jest to prawo naturalne post naturam.

Cały jednak przedstawiony tu porządek bytowo-przyczynowych zależności ujawnił się nam w rezultacie refleksji, zmierzającej do wyjaśnienia swoistych, realnie danych i bezpośrednio stwierdzalnych faktów, faktów bezwzględnej powinności moralnej. Z punktu widzenia poznawczego (in ordine cognoscendi) kolejność naszych kondygnacji jest zatem odwrotna. Na początku umiejscawia się fakt powinności. On się nam wprost i bezpośrednio uobecnia $w$ aktach sumienia. On w swej specyfice nas i praktycznie niepokoi i teoretycznie frapuje. On zmusza do stawiania pod jego adresem określonych pytań, które stają się nosicielami zapotrzebowania poznawczego na określone odpowiedzi, czyli na określoną teorię wyjaśniającą i uzasadniającą. On zatem jest punktem wyjścia i kondygnacją poznawczo pierwszą i podstawową. Na niej, w oparciu o rozumowanie redukcyjne, którego swoistość w tym przypadku polega na szukaniu przyczyn adekwatnie wyjaśniających (jedynie uniesprzeczniających zachodzenie faktów w ich własnej specyfice), nadbudowaliśmy dwie dalsze kondygnacje. Nadbudowaliśmy je powodowani koniecznością wyjaśnienia ostatecznościowego kondygnacji pierwszej.

$\mathrm{W}$ tym właśnie sensie przedstawiona tu skrótowo teoria prawa naturalnego jest wynikiem myślenia kategoriami realizmu i empiryzmu. Utrzymuje się ona w mocy, bądź upada $\mathrm{z}$ chwilą, gdy tylko pozwolimy sobie choćby $\mathrm{w}$ najmniejszym stopniu na nie-realistyczne traktowanie samych faktów i nie-empiryczne do nich podejście. Nie obawiamy się jednak ani ,upadku” ani ,kryzysu" przedstawionej teorii prawa natu-

${ }^{42} \mathrm{~W}$ tym sensie mówi się niekiedy o sumieniu jako o ,głosie Boga do człowieka” lub jako „wołaniu Boga”. 
ralnego. Zbyt mocno jesteśmy przekonani o wartości poznawczej założenia realizmu - jedynego zresztą - na jakim ją budujemy. Wierzymy, że na dłuższą metę nie podobna ignorować faktu. Wierzymy dalej, że nikt uznawszy go, nie zechce kwestionować jedynie uniesprzeczniającej go racji ${ }^{43}$. Racją tą okazuje się natura ludzka jako persona icarnata ab Alio. W pojęciu osoby ludzkiej mieści się oczywiście wolność. Pełna jej afirmacja musi zatem wejść w skład realistycznej teorii prawa naturalnego. Równocześnie jednak pamiętać musimy, że chodzić tu może jedynie o afirmację realnej wolności ludzkiej, tj. wolności „osoby wcielonej a b A l o" ${ }^{44}$. Zrozumiałe więc, że wszelka teoria, która usiłuje określić wolność człowieka w sposób naruszający rzeczywisty status ontyczny człowieka, prowadzić musi tym samym do przekreślenia prawa naturalnego, nawet gdyby skądinąd czyniła wszystko dla zatrzymania jego nazwy. Trzeba jednak dodać, że zanim jej się uda ugodzić w prawo naturalne, wpierw musi się ona rozstać z realnością faktów. Dla nas oznacza to tyle, co ugodzić w swe własne podstawy.

\section{RES U M E}

\section{LA CONCEPTION PHILOSOPHIQUE DU DROIT NATUREL}

La conception du droit naturel est née d'une réflexion sur l'explication philosophique des faits comme le devoir absolu de prendre des décisions ou d'agir. Les devoirs absolus se distinguent: solit des devoirs à cause de l'autorité de pouvoir ou d'une pression du milieu social (devoirs thétiques), soit des devoirs à cause du but nécessaire (devoirs téléologiques). Dans le cas des devoirs aibsolus, le but n'est pas défini délibérément, mais il est donné de manière objective et qui ne présente qu'une valeur digne de l'affirmation par elle même (non à cause d'autre raison!).

C'est la dignité de la personne humaine qui est un but et une valeur. C'est la dignité de celui à qu'on se décide (objet) et, en même temps, de celui qui agit (sujet). Conformément à cela, le devoir absolu signifie ce devoir d'agir pour qui la dignité de la personne humaine est une raison suffisante. D'autres raisons sont exclues, au moins quand il y a peu d'importance. Ces devoirs sont identiques, dans le contenu et dans l'étendue, aux devoirs moraux.

Les devoirs moraux sont uniques dans leur genre. Ils sont et peuvent être donnés directement dans les faits de connaissance (conscience). Ils ont le caractère de l'acte et du fait psychique, mais leur objet n'est point un acte psychique. Néanmoins, leur objet est réel et il porte le nom du fait. C'est le fait moral. Les actes

43 W tym przypadku w sukurs faktom (realizmowi) przychodzi logika. „Jak powiedział McTaggart nikt jeszcze nie przełamał praw logiki, a złamały niejednego". Cyt. za B. Blanshard, Czy ludzie moga być rozumni?, w: Flozofia amerykańska, Boston 1958, 120.

44 Por. również $R$. Ingarden: Utber die Verantwortung. Ihre ontische Fundamente, Stuttgart 1970. 
de connaissance méritent justement le nom de l'expérience. C'est une expérience de la morale.

C'est la psychologie de la morale qui s'occupe des actes comme des processus psychiques. La théorie de connaissance éthique et la méthodologie d'éthique (métaéthique) s' occupent de ces actes comme sources et critères de la science de l'événement moral. Cet événement (devoir dans l'expérience de devoir) est, lui même, l'objet de l'éthique ou — si l'on préfère ainsi — de la théorie du droit naturel.

Le contenu et la nature des faits moraux, à cause de leur position spécifique dans la vie de l'homme, décident qu'on ne peut plus donner une pure constatation. Sous l'influence des besoins pratiques et des inquiétudes théorétiques, on demande parfois comme voici: „Pourquoi je dois, moi même (ainsi)?”, „Pourquoi je dois quelque chose en général?". Ces demandes expriment le besoin d'expliquer ultérieurement les faits moraux, lorsqu'ils ont de la nature expérimentelle.

L'auteur souligne que la recherche d'une explication se retrouve dans la structure totale, statique et dynamique, de l'homme en tant qu'il est sous l'influence de l'amour créatif de l'Absolu Personnel de l'Etre. La structure conçue ainsi, c'est la nature humaine vue intégralement comme, ,persona incarnata ab Alio et ad A(a)lium sicut ad suum A(a)ctum". Dans son sens réel, elle se présente avant tout comme une fonction d'un principe qui explique expérimentalement les faits moraux. En même temps, elle possède une fonction révélatrice (à travers la raison, la conscience) du plan de "Tu" transcendant, le plan qui est étérnel mais aussi temporel. C'est une fonction propre de ce qui s'appelle d'autre part un droit. Etant une raison des faits moraux, la nature humaine est, en même temps, le droit moral naturel. Le caractère personnel du droit naturel a été défini par le caractère existentiel de la nature humaine: c'est une ,propriété" de „moi" de l'homme (personne), une propriété en tant qu'elle est le don de „Tu" transcendant (Personne).

L'auteur souligne que la raison des faits moraux a le caractère apodictique: c'est une seule raison qui explique les faits moraux qui ne peuvent être autres. La nécessité d'accepter le droit naturel n'est que le résultat et le postulat d'une connaissance de réalité empirique. C'est pourquoi la „crise du droit naturel” est un phénomène dans la sphère de la méthodologie de connaissance, mais elle ne touche point le droit naturel comme tel. 